\title{
REGULATORY EFFECTS OF STEROIDS ON THE PITUITARY RESPONSE TO LH-RH
}

\author{
C. Gual, H. E. SCAGlia, R. A. Midgley JR., J. Alcocer, \\ Y. ECHEVERRIA-RIVAS and R. LICHTENBERG*
}

From the Department of Reproductive Biology, Instituto Nacional de la Nutrición. Mćxico 22, D. F. Mćxico, and the Department of Pathology, University of Michigan, Ann Arbor, Michigan, U.S.A.

\section{SUMMARY}

\begin{abstract}
The pituitary response to a continuous i.v. LH-RH administration $(15 \mu \mathrm{g} / \mathrm{h} / 3 \mathrm{~h})$ associated with physiological or pharmacological doses of several steroid hormones such as estradiol $\left(E_{2}\right)$, progesterone, $17 \alpha \mathrm{OH}$-progesterone, 20 $\alpha \mathrm{OH}$-progesterone, chlormadinone acetate, testosterone $(\mathrm{T})$ and $5 x$-dihydrotestosterone $(5 \alpha \mathrm{DHT})$ was evaluated by radioimmunoassayable plasma LH and FSH measurements, in normal and post-menopausal women, normal men, and in a Flinefelter's syndrome subject. Analysis of results indicated that $E_{2}$ in doses of $132 \mu \mathrm{g} / \mathrm{h} / 6 \mathrm{hs}$ blocks the pituitary response to $\mathrm{LH}-\mathrm{RH}$ in all cases except in the Klinefelter's syndrome patient. Nevertheless, $E_{2}$ in doses of $66 \mu \mathrm{g} / \mathrm{h} / 6 \mathrm{hs}$ did not cause a significant inhibitory effect. The infusion of physiological $(330 \mu \mathrm{g} / \mathrm{h} / 6 \mathrm{hs})$ or pharmacological $(3300-6600 \mu \mathrm{g} / \mathrm{h} / 6 \mathrm{hs})$ doses of any of the selected progestational steroids did not block the pituitary response to $\mathrm{LH}-\mathrm{RH}$. When chlormadinone acetate was infused together with $\mathrm{E}_{2}$ in normal and postmenopausal women, the inhibitory effect of $\mathrm{E}_{2}$ on the pituitary response to LH-RH was antagonized. $\mathrm{T}$ in doses of $600 \mu \mathrm{g} / \mathrm{h} / 6 \mathrm{hs}$ produced a partial inhibitory effect on the pituitary response to LH-RH in normal men, nevertheless in the post-menopausal women and in the Klinefelter's syndrome patient did not cause inhibition. 5xDHT did not inhibit the pituitary response to LH-RH administration in all subjects tested. It was concluded that: (1) pharmacological doses of $E_{2}$ completely blocks the pituitary response to $\mathrm{LH}-\mathrm{RH}$; (2) the inhibitory effect of $\mathrm{E}_{2}$ was counteracted by chlormadinone acetate; (3) the infusion of $\mathrm{T}$ produced a partial inhibitory effect on the pituitary response to $\mathrm{LH}-\mathrm{RH}$ in normal men, and (4) in the patient with Klinefelter's syndrome, the infusion of pharmacological doses of $T$ and $E_{2}$ did not inhibit the $L H$ pituitary response to $L H-R H$.
\end{abstract}

\section{INTRODUCTION}

Numerous studies in laboratory animals and man indicate that sex steroids play an important role on the feedback regulation of the synthesis and release of pituitary gonadotropins, either by a direct effect on the pituitary gland or through its action on the hypothalamus.

The identification of porcine LH-RH by Matsuo et al. 1971[1] permitted the synthesis of a decapeptide with physicochemical and biological properties identi$\mathrm{cal}$ to natural $\mathrm{LH}-\mathrm{RH}[2-5]$, including the ability to release both $\mathrm{LH}$ and $\mathrm{FSH}$ from the pituitary gland [6-7]. Availability of the synthetic decapeptide has permitted several clinical investigators to test in the human the pituitary response to $\mathrm{LH}-\mathrm{RH}$ administration under selected experimental conditions and particularly after administration of different sex steroids.

Although most of the recent publications have contributed to our knowledge on the mechanisms in-

$t$ in the control of gonadotropin secretion, there "v contradictory results, and numerous ments remain to be elucidated.

$y$

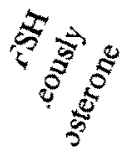

should be sent to: $\mathrm{Dr}$ al de la Nutrición. Viaducto exico 22, D.F.

Fellow. Training Program in ituto Nacional de la Nutrición a.
In this communication, our more recent studies conducted to evaluate hormonal responses to constant intravenous infusions of $\mathrm{LH}-\mathrm{RH}$ associated with either physiological or pharmacological doses of selected natural or synthetic sex steroids in normal and post-menopausal women, normal men and a Klinefelter's syndrome patient will be presented.

\section{EXPERIMENTAL}

Synthetic LH-RH was provided by Farwerke Hoechst, A. C., Frankfurt, Germany, in sterile ampoules each containing $25 \mu \mathrm{g}$ of lyophilized decapeptide. The selected steroids were recrystallized several times prior to use and shown to be highly pure by appropriate paper chromatography. A total of 62 tests were performed in 4 post-menopausal women, 4 normal women in different phases of the menstrual cycle, 2 normal men, and in one subject with Klinefelter's syndrome (XXY). The weighed steroids were infused intravenously in all subjects for a 3 or $6 \mathrm{~h}$ period as a 0.2 to $0.5 \%$ ethanolic solution in $1000 \mathrm{ml}$ of isotonic saline. The steroids were infused at a rate of 6.6 and $132 \mu \mathrm{g} / \mathrm{h}$ for estradiol; 330 and $3300 \mu \mathrm{g} / \mathrm{h}$ for either progesterone, $17 \alpha \mathrm{OH}$-progesterone, $20 \alpha \mathrm{OH}$-progesterone or chlormadinone acetate; 60,600 and $1200 \mu \mathrm{g} / \mathrm{h}$ for testosterone; and 6 and $60 \mu \mathrm{g} / \mathrm{h}$ for $5 a$-dihydrostestosterone. Studies were initiatcd between 8 a.m. and 9 a.m. and the solution 


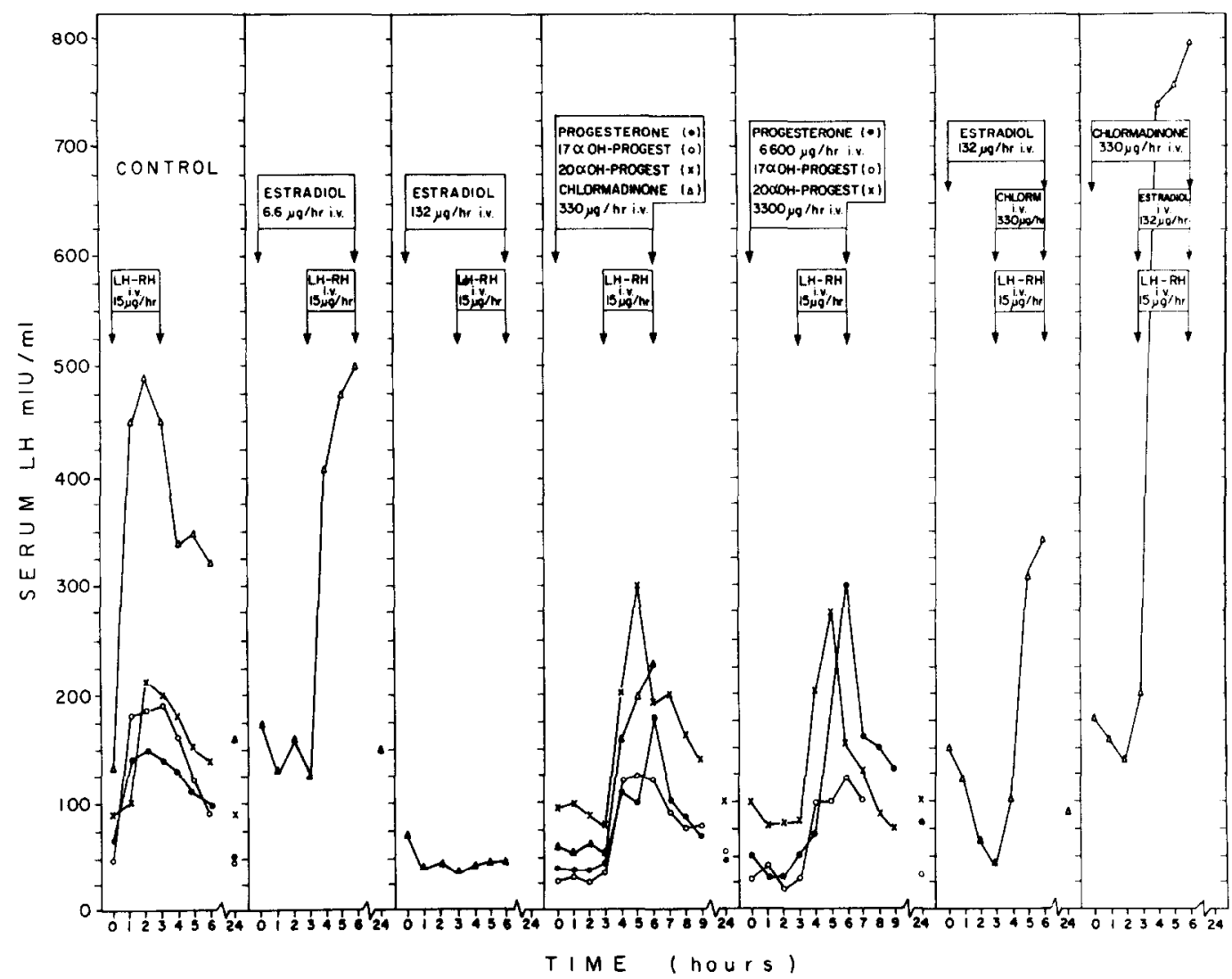

Fig. 1. Steroid effect on the pituitary LH response to $\mathrm{LH}-\mathrm{RH}$ in post-menopausal women. $(\triangle)$ B.G. age $49 ;(\times)$ M.G. age $49 ;(1)$ C.C. age $55 ;(0)$ J.S. age 50 .

administered at a rate of $166 \mathrm{ml} / \mathrm{h}$ through an indwelling i.v. catheter with the subjects in sitting position.

LH-RH was infused alone in control tests or associated with the selected steroid for the last $3 \mathrm{~h}$ of infusion at a rate of $15 \mu \mathrm{g} / \mathrm{h}$.

In the 4 normal menstruating women, the infusion tests were performed either in the early proliferative phase of the cycle (day 6), in the midcycle (days 12-14) or at the mid-luteal phase (day 22). In the post-menopausal women, normal men and in the Klinefelter's Syndrome patient, the infusions were done 7-15 days apart.

In all cases the pituitary response was evaluated by serum LH and FSH measurements in blood samples withdrawn from the catheter at time 0 and at $1-9$, and $24 \mathrm{~h}$ after the initiation of the infusion. After centrifugation, the serum was separated and kept frozen at $-20^{\circ} \mathrm{C}$ until assayed. Serum LH and FSH levels were determined by double antibody radioimmunoassay according to previously described methodology $[8,9,10]$.

\section{RESULTS}

\section{Postmenopausal women}

As illustrated in Fig. 1, a $3 \mathrm{~h}$ LH-RH administration at a rate of $15 \mu \mathrm{g} / \mathrm{h}$ in 4 post-menopausal women caused a significant $\mathrm{LH}$ increase, with a peak rise after 2 or $3 \mathrm{~h}$ of infusion. When in one of these women LH-RH was administered along with a constant estradiol infusion at a rate of $66 \mu \mathrm{g} / \mathrm{h}$ for 6 consecutive hours, which is comparable to the normal blood production rate of estradiol during the menstrual cycle of the normal women, a peak rise similar to that of the control test in the same patient was obtained. On the contrary, when estradiol was infused at a rate of $132 \mu \mathrm{g} / \mathrm{h}$, which is about $10-20$ times above the normal blood production rate in the normal menstruating women, the pituitary LH response was completely blunted.

Progesterone, $17 x \mathrm{OH}$-progesterone and $20 \alpha \mathrm{OH}$ progesterone infused in doses similar to the normal blood production rate seen during the luteal phases of the menstrual cycle or in doses 10 times higher did not inhibit the pituitary LH response to the prolonged LH-RH administration. Similar results were obtained when chlormadinone acetate was infused in doses of $330 \mu \mathrm{g} / \mathrm{h} / 6$ consecutive hours.

When chlormadinone acetate was administered as a mixture with pharmacological doses of estradiol, a normal or even enhanced $\mathrm{LH}$ response was induced by the $3 \mathrm{~h} \mathrm{LH}-\mathrm{RH}$ infusion.

As shown in Fig. 2, the FSH responses obtained during the same LH-RH tests were comparable bu of lesser magnitude than those observed for $\mathrm{LH}$.

Figures 3 and 4 depict a normal LH and ' pituitary response to $\mathrm{LH}-\mathrm{RH}$ simultap administered during the last $3 \mathrm{~h}$ of the test 


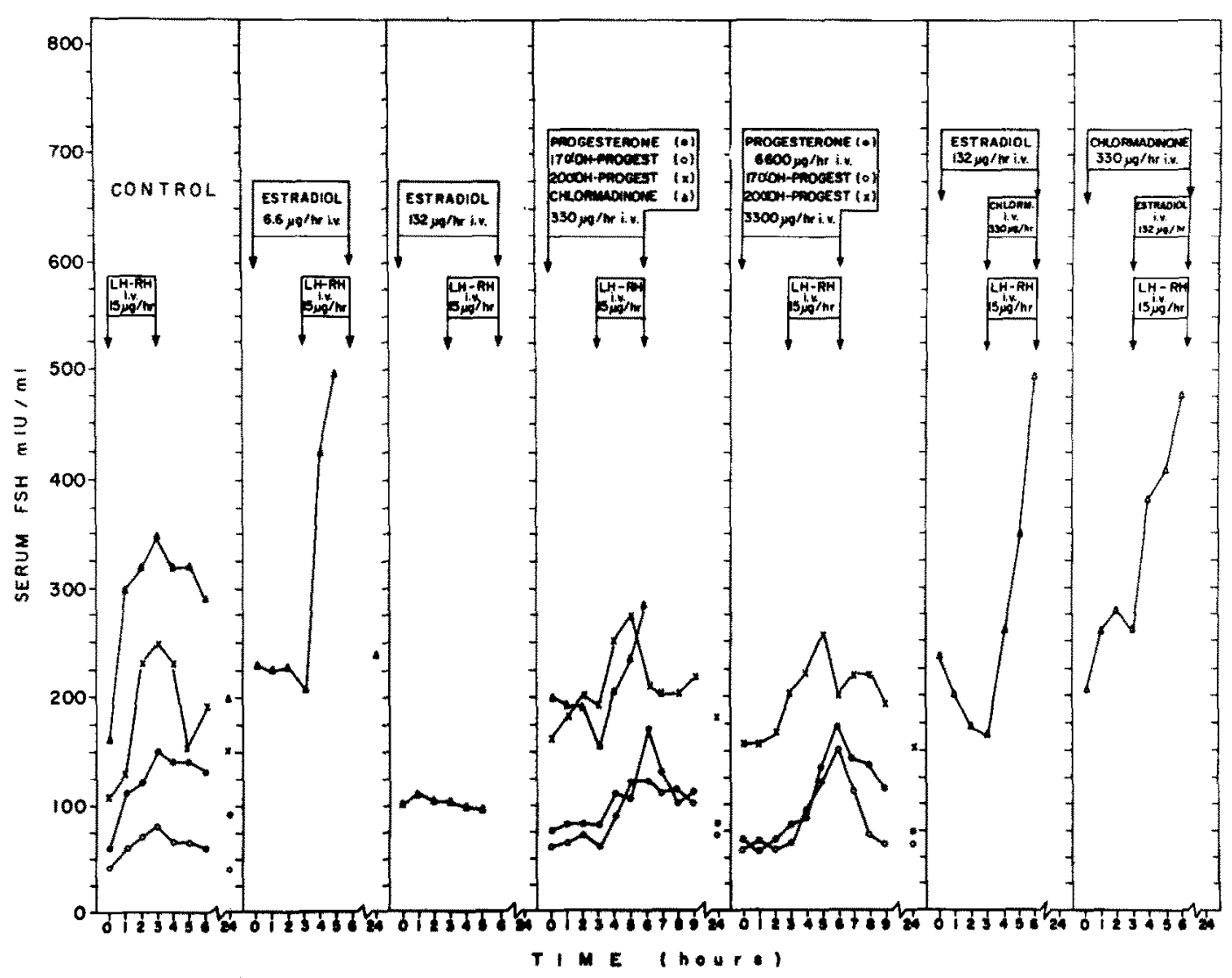

Fig. 2. Steroid effect on the pituitary FSH response to $L H-R H$ in post-menopausal women. $(\triangle)$ B.G. age $49 ;(\times)$ M.G. age $49 ;(\bullet)$ C.C. age $55 ;(0)$ J.S. age 50 .

and $5 \alpha$-dihydrotestosterone infusions in doses of 60 or $600 \mu \mathrm{g} / \mathrm{h}$ and 6 or $60 \phi \mu \mathrm{g} / \mathrm{h}$ respectively, for 6 consecutive hours.

\section{Normal women}

Figure 5 shows the effects of prolonged intravenous infusions of various regimens of estradiol and chlor- madinone acetate on the $\mathrm{LH}$ response to a $3 \mathrm{~h} \mathrm{LH}-$ RH administration in different phases of the menstrual cycle of young normal women. When estradiol was infused on day 6 of the menstrual cycle at a rate of $6.6 \mu \mathrm{g} / \mathrm{h}$, the pituitary I.H responses to I.H-RH were similar to those observed in the early follicular phase of control LH-RH tests [11]; when infused in

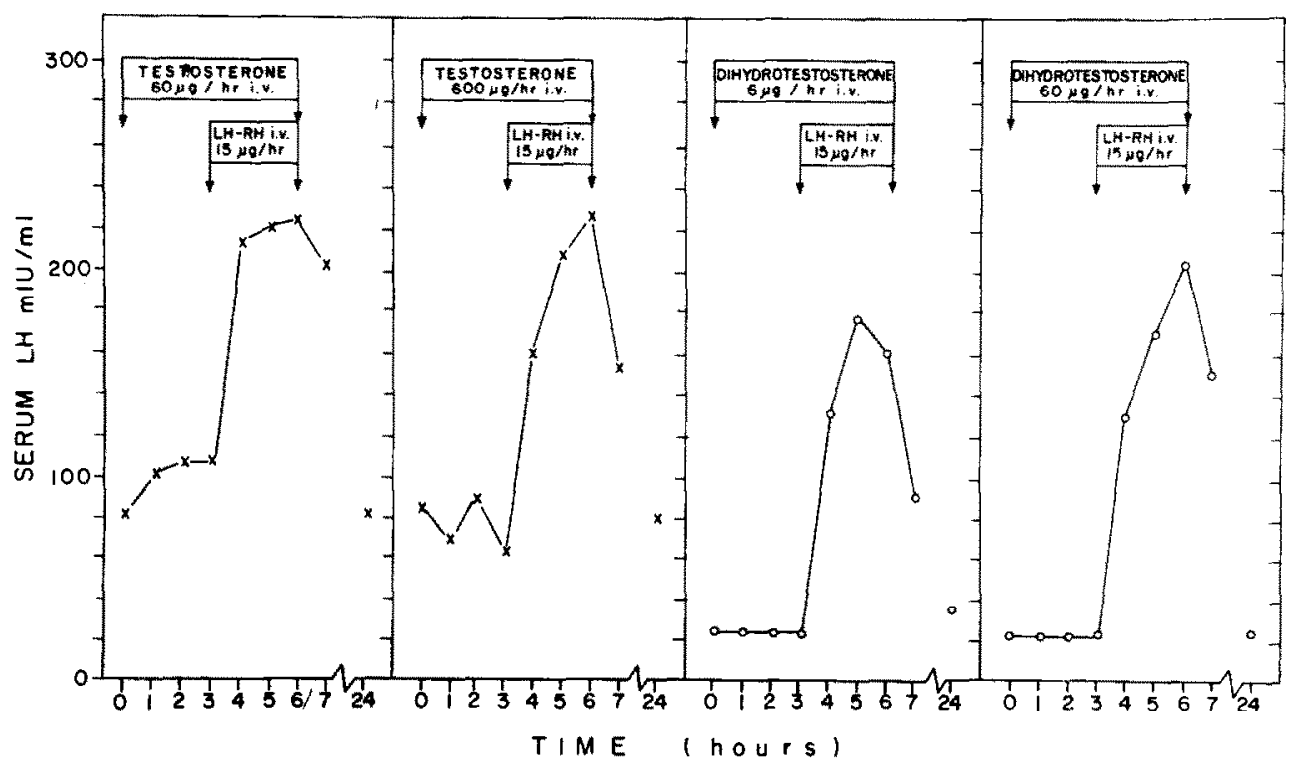

Fig. 3. Androgen effect of the pituitary LH response to LH-RH in post-menopausal women. $(x)$ M.G. age 49 ; (O) J.S. age 50 . 


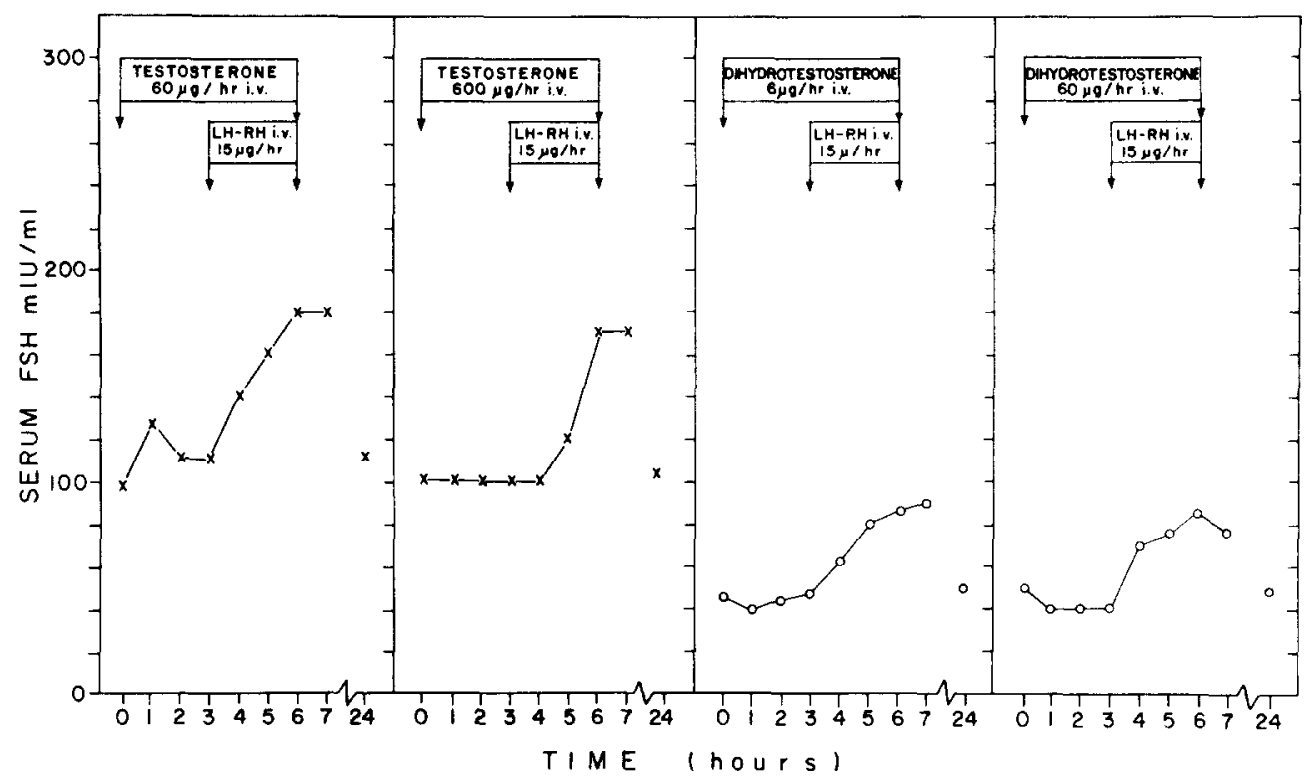

Fig. 4. Androgen effect on the pituitary FSH response to LH-RH in post-menopausal women. $(x)$ M.G. age $49 ;(0)$ J.S. age 50 .

doses ranging 10-20 times above the normal blood production rate of normal menstruating women $(132 \mu \mathrm{g} / \mathrm{h})$, the $\mathrm{LH}$ response was completely blunted in a fashion similar to that observed above in the post-menopausal women.

When chlormadinone acetate was infused on day 22 of the menstrual cycle at a rate of $330 \mu \mathrm{g} / \mathrm{h}$, it did not inhibit the pituitary LH response to LH-RH but induced an antagonistic action of the blocking effect of pharmacological doses of estradiol on the pituitary response to $\mathrm{LH}-\mathrm{RH}$ stimulation (see right side of Fig. 5).

The FSH responses were similar but of lesser magnitude than those already observed for $\mathrm{LH}$ (Fig. 6).

\section{Normal men}

Figure 7 depicts the effects of several steroid hormones on the LH pituitary response to LH-RH

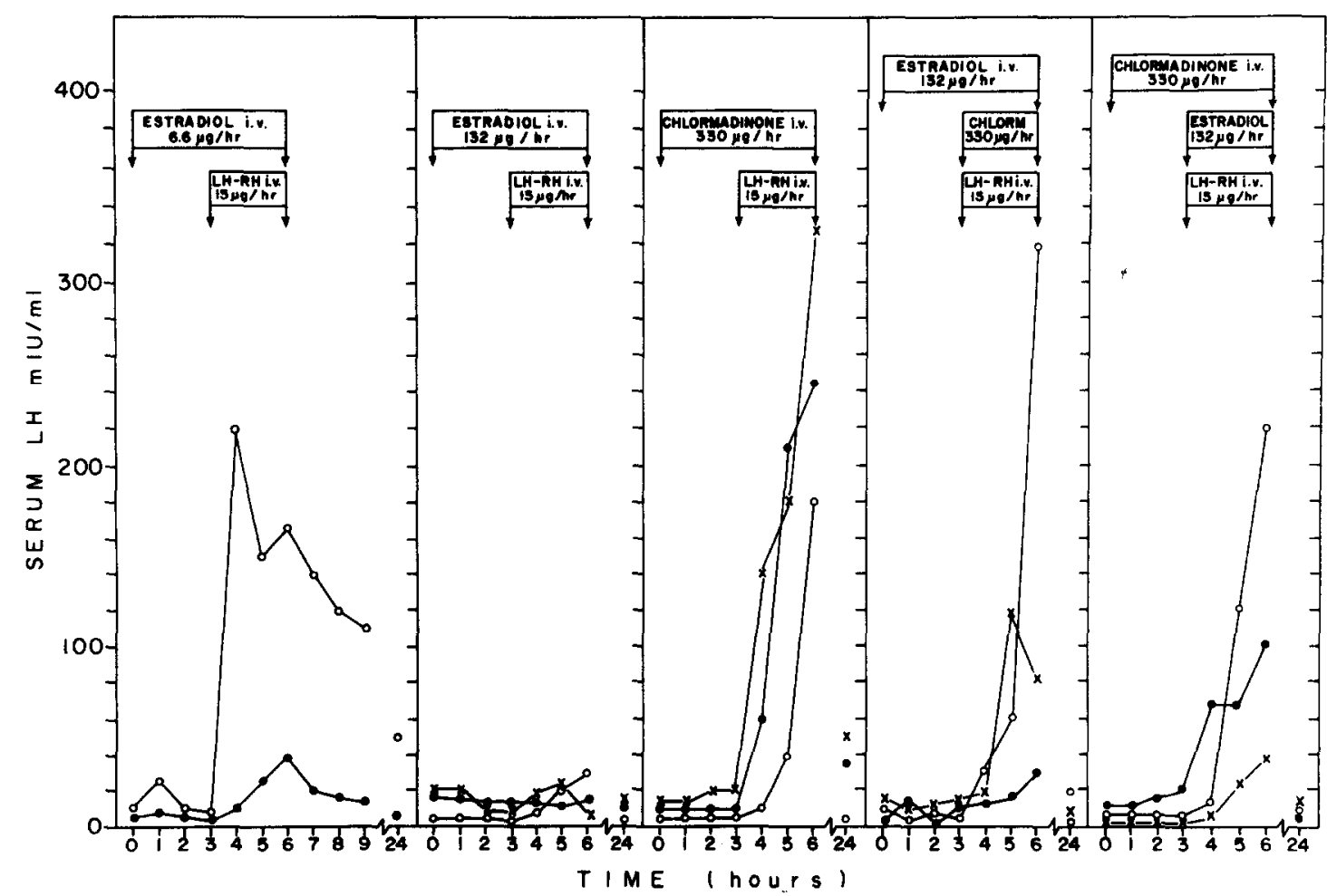

Fig. 5. Steroid effect on the pituitary LH response to LH-RH in normal women. $(\times)$ M.L.G. age 24; (๑) M.G. age 30; (O) C.R. age 32. 


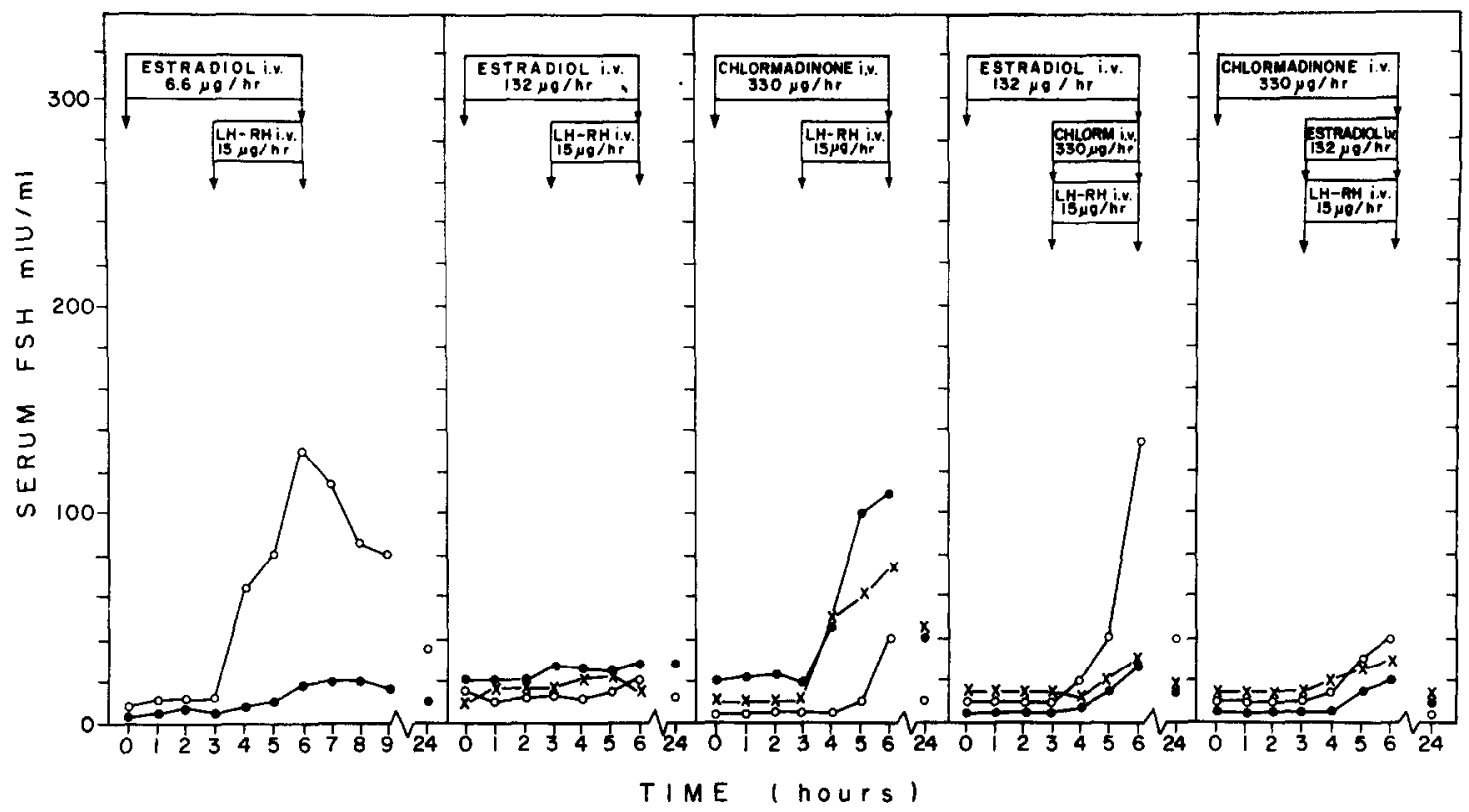

Fig. 6. Steroid effect on the pituitary FSH response to LH-RH in normal women. ( $\times$ ) M.L.G. age 24; (•) M.G. age 30; (O) C.R. age 31 .

administration in 2 normal men. On the left side of the figure are depicted the responses to LH-RH alone. The infusion of $132 \mu \mathrm{g} / \mathrm{h}$ of estradiol completely blocked the pituitary response to LH-RH. Chlormadinone acetate did not inhibit the pituitary $\mathrm{LH}$ response and even in one case enhanced the re- sponse. Testosterone infused in doses of 600 and $1200 \mu \mathrm{g} / \mathrm{h}$ partially blocked the pituitary response to LH-RH and 5 $x$-dihydrotestosterone in doses of $60 \mu \mathrm{g} / \mathrm{h}$ did not show any inhibitory effect as compared with the control LH-RH tests.

The administration of LH-RH along with the

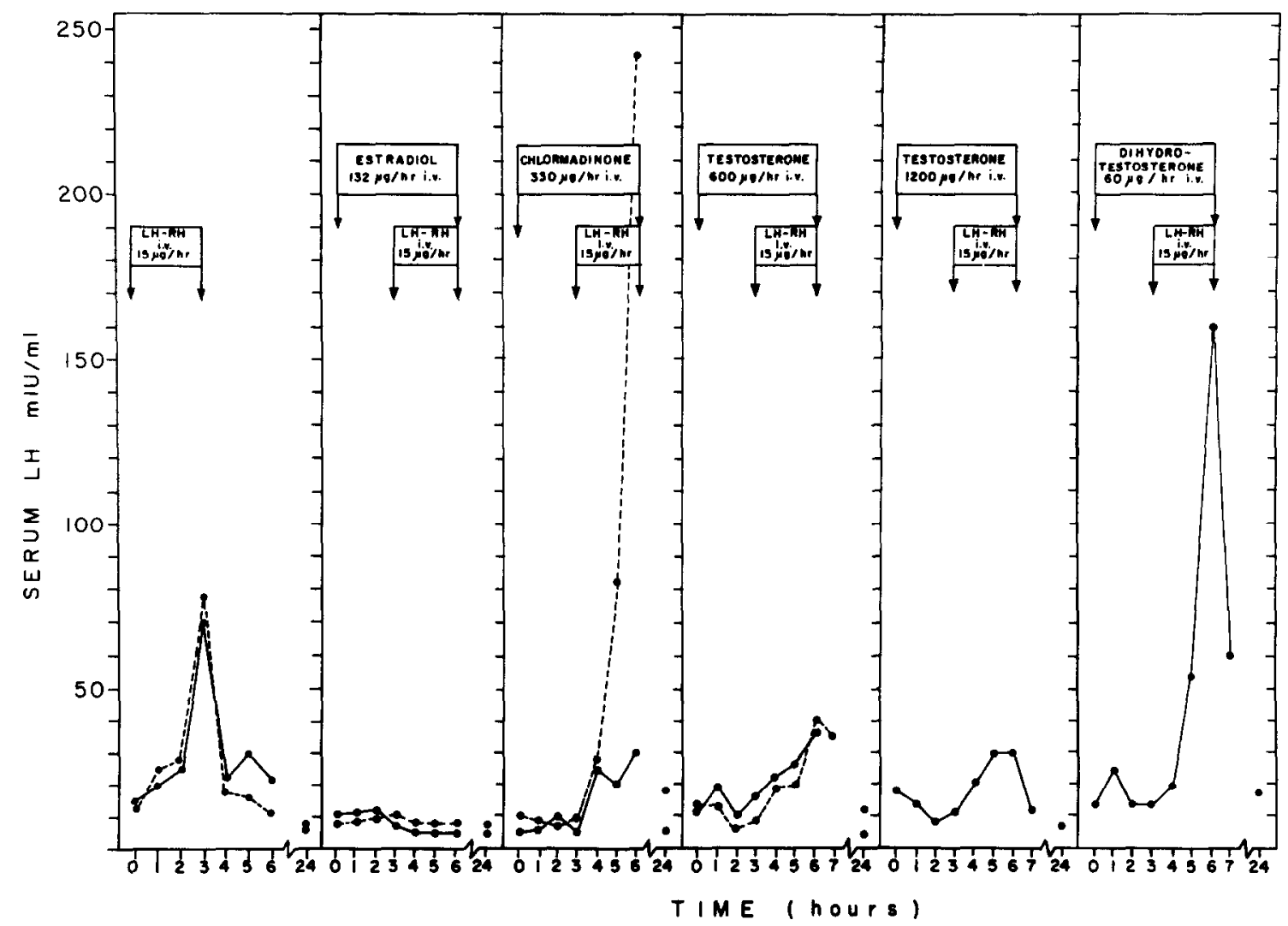

Fig. 7. Steroid effect on the pituitary LH response to LH-RH in normal men. (-) R.G. age 35; (---) R.L. age 24. 


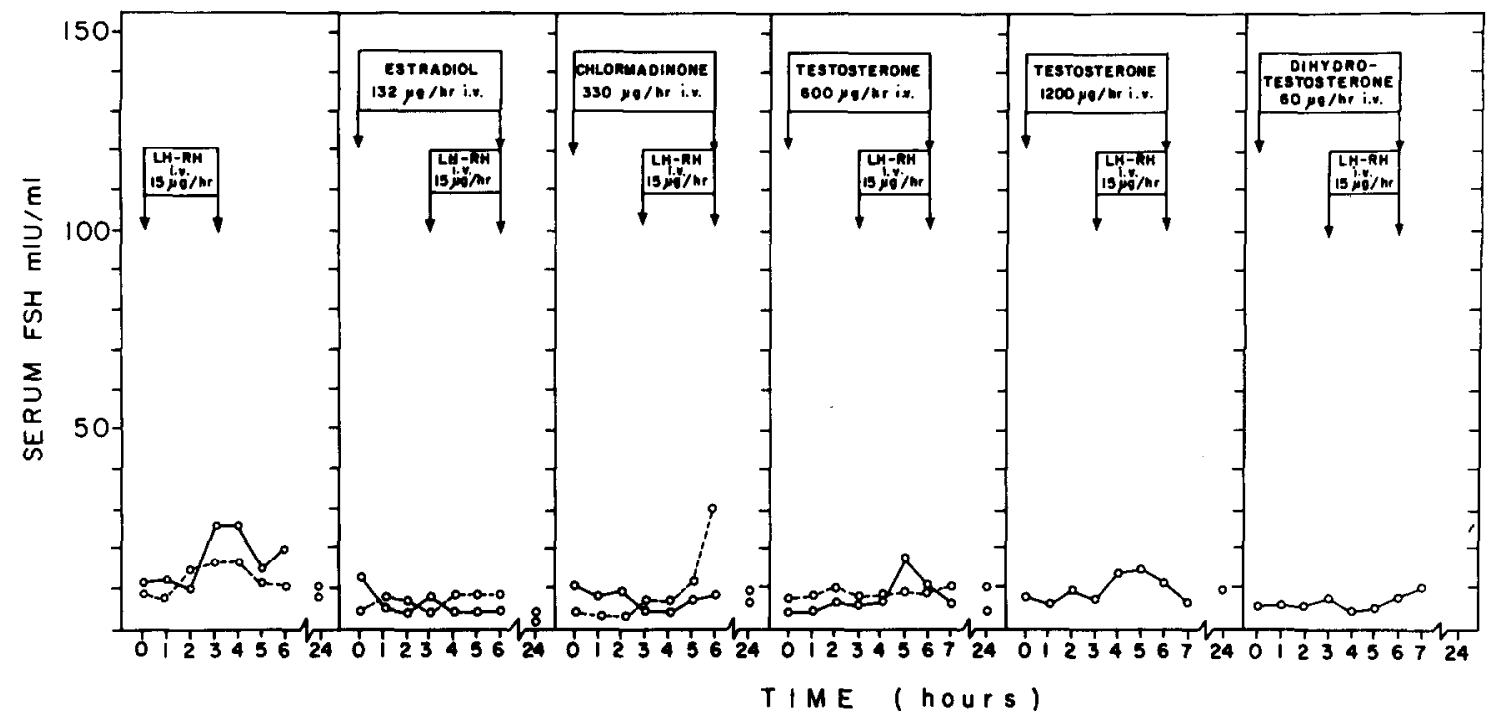

Fig. 8. Steroid effect on the pituitary FSH response to LH-RH in normal men. (--) R.G. age 35;

(--.-) R.R. age 24.

steroid hormones shown in Figure 8, induced smaller FSH responses than those observed in the control tests with $\mathrm{LH}-\mathrm{RH}$ injected alone.

\section{Klinefelter's syndrome}

Figure 9 shows the LH and FSH pituitary response to LH-RH infused alone or associated with several steroids in one Klinefelter's syndrome patient. On the control test the peak rise for LH was observed at $120 \mathrm{~min}$ of infusion with a delta value of $110 \mathrm{mIU} / \mathrm{ml}$. FSH increase was seen at $180 \mathrm{~min}$ with a secondary rise for the following $3 \mathrm{~h}$ to give a final delta value of $63 \mathrm{mIU} / \mathrm{ml}$. Constant infusion of estradiol in doses similar to the blood production rate in normal

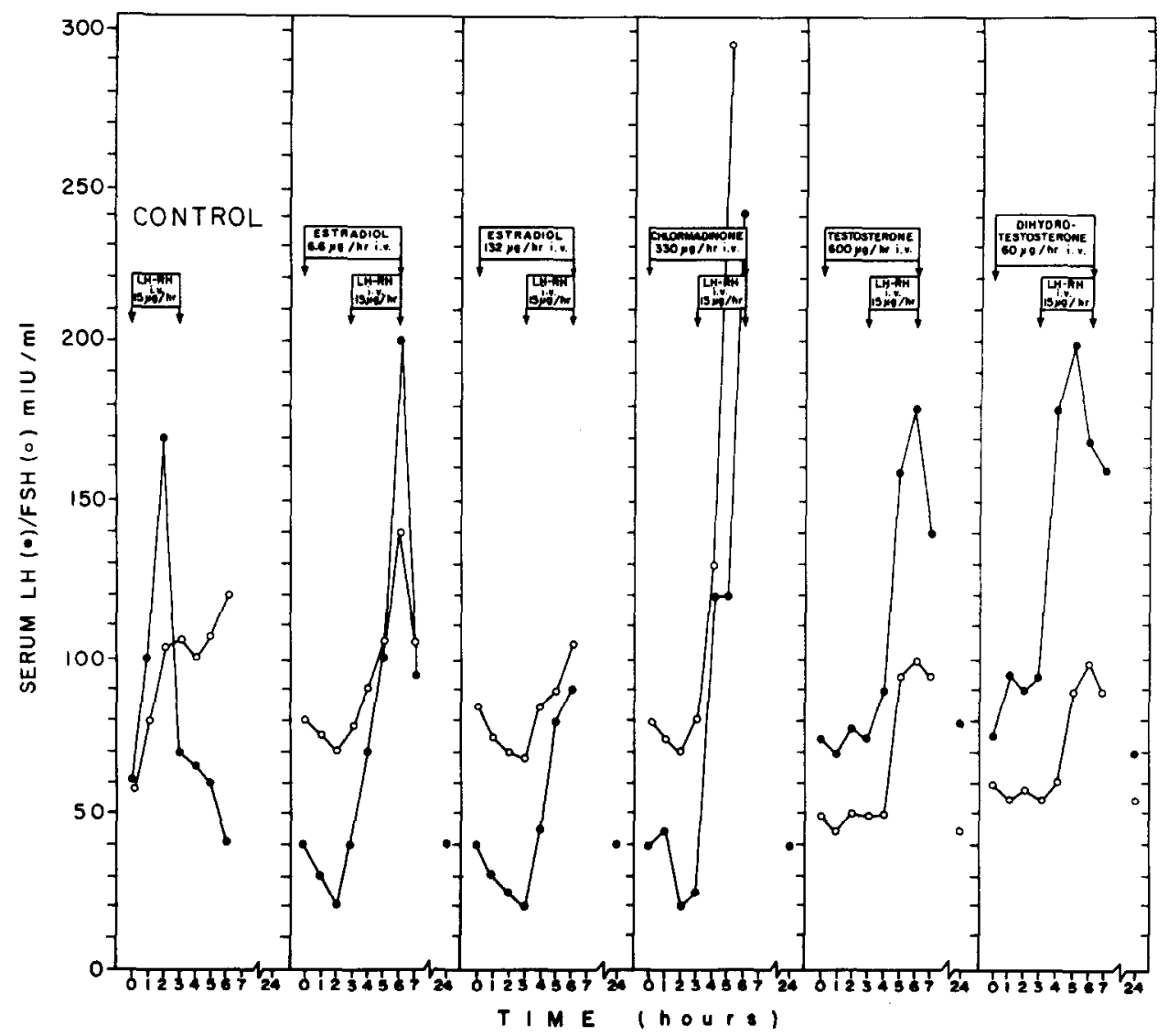

Fig. 9. Steroid effect on the pituitary response to LH-RH in a Klinefelter's Syndrome patient (47, $\mathrm{XXY}$. 
women does not inhibit the pituitary LH and FSH responses to LH-RH. When pharmacological doses of estradiol were infused, a discrete diminished $\mathrm{LH}$ and FSH response was noticed, but a complete inhibition was not observed as previously demonstrated in normal and post-menopausal women and normal men. Infusion of chlormadinone acetate induced augmented pituitary LH and FSH responses as compared to the control LH-RH test. Testosterone and $5 \alpha \mathrm{DHT}$ infused at a rate of $600 \mu \mathrm{g} / \mathrm{h}$ and $60 \mu \mathrm{g} / \mathrm{h}$, respectively. did not inhibit the pituitary response to LH-RH.

\section{DISCUSSION}

The present study demonstrates that a constant infusion of physiological doses of estradiol does not inhibit the response of pituitary gonadotropins to synthetic LH-RH in normal and post-menopausal women. Nevertheless, when estradiol is infused at a rate of $132 \mu \mathrm{g} / \mathrm{h}$, which is about $10-20$ times above the normal blood production rate in normal menstruating women, the pituitary LH and FSH responsiveness to $\mathrm{LH}-\mathrm{RH}$ is completely inhibited. This inhibitory effect can be antagonized by a simultaneous infusion of a synthetic progestogen and probably by one or more of the known natural progestational steroids. These observations confirm and extend our original studies carried out during the follicular and luteal phase of the menstrual cycle of normal and post-menopausal women [12]. In this regard, Keye and Jaffe[13] observed in normal menstruating women a direct inhibitory effect of estradiol upon the pituitary gonadotropins and suggested that increasing concentrations of estradiol were not solely responsible for the increased pituitary responsiveness to $\mathbf{L H}-\mathbf{R H}$ at midcycle. More recently, Yen et al. [14] reported that a constant infusion for $6 \mathrm{~h}$ of pharmacological doses of estradiol exerts a direct negative feedback action on the pituitary gonadotrophs of hypogonadal hypergonadotropic subjects, thus confirming in part our previous findings in post-menopausal women.

It is important to differentiate clearly between pharmacologic versus physiologic effects of sex steroids on the responsiveness of pituitary gonadotropins to synthetic LH-RH. In our studies it was evident that only pharmacological levels of estradiol were capable of blocking the LH-RH pituitary responsiveness and that lower doses selected to mimic the estrogen production rate which exist in the late follicular phase of the menstrual cycle did not signifcantly modify the LH-RH pituitary gonadotropin responsiveness.

The results obtained in normal men demonstrate that a constant infusion of estradiol in doses of $132 \mu \mathrm{g} / \mathrm{h}$ completely inhibited the pituitary gonadotropin responses to $\mathrm{LH}-\mathrm{RH}$ administration. On the contrary, testosterone only produced a partial inhibitory effect, and $5 \alpha$-dihydrotestosterone and chlormadinone acetate did not affect the pituitary responsiveness. It has been reported [15-19] that testosterone and estradiol inhibit the pituitary gonadotropin secre- tion in men, which can be explained by a diminished sensitivity of pituitary gonadotrophs to LH-RH, although a direct negative feedback action on the hypothalamic LH RH release can not be excluded.

Interesting enough were the responses obtained in the Klinefelter's syndrome patient in whom testosterone and estradiol did not inhibit the pituitary LH and FSH responsiveness to $\mathrm{LH}-\mathrm{RH}$ administration. These findings explain in part previous reports on the refractoriness of the hypothalamic pituitary axis to the inhibitory effects of the natural gonadal hormones [20-23].

On the basis of the data presented in this paper, it can be concluded that sex steroids can modulate the hypothalamic-pituitary axis and that estradiol alone does not seem to increase the pituitary sensitivity to LH-RH since it is not solely responsible for the increased pituitary responsiveness present at the mid-luteal phase. In addition, our data suggest the hypothesis that the increased pituitary responsiveness which facilitates the midcycle LH and FSH surge might be conditioned by the synergistic effect of estradiol and a progestin steroid such as progesterone, $17 x$-hydroxyprogesterone and the $20 x$ or $20 \beta$ reduced derivative of progesterone.

Acknowledgements-This work was supported by Ford Foundation Research and Training Grant No. 650-025B. Antigens and antisera for FSH and LH radioimmunoassay were kindly supplied by the N.I.A.M.D.D., National Institutes of Health (U.S.A.).

\section{REFERENCES}

1. Matsuo H. Baba Y., Nair R. M. G., Arimura A. and Schally A, V.: Biochem. biophys. Res. Commun, 43 (1971) 1334-1339.

2. Geiger R., Köning W, Wissmann H., Geisen K. and Enzmann F.: Biochem. biophys. Res. Conmun. 45 (1971) $767-773$.

3. Matsuo H. Arimura A. Nair R. M. G. and Schally A. V.: Biochem hiophys. Res. Commun 45 (1971) 822827.

4. Milhaud G., Rivaille P., Garnier P., Chaussain J. L., Binet E. and Job J. C.: C.r. hebd. Séanc. Acad. Sci. (Paris) 273 (1971) \$858-1861.

5. Monahan M., Rivier J., Burgus R.., Amoss M., Blackwell R., Vale W. and Guillemin R.: C.r. hebd. Seanc. Acad. Sci. (Paris) 273 (1971) 508-510.

6. Arimura A., Matsuo H., Baba Y., Debeljuk L., Sandow J. and Schally A. V.: Endocrinology 90 (1972) 163-168.

7. Schally A. V., Arimura A., Kastin A. J., Matsuo H., Baba Y., Redding T. W., Nair R. M. G., Debeljuk L. and White W. F.: Science 173 (1971) 1036-1037.

8. Midgley A. R. Ir.: Endocrinology 79 (1966) 10-18.

9. Midgley A. R. Ir.: J. elin. Endocr. Metab. 27 (1967) $295-299$.

10. Pérez-Palacios G. Iramain C. A., Castañeda E., Rojo B., Long D. W., Scaglia H. E., Gual C.: Rev. Invest. Clin. 25 (1973) 305-313.

11. Gual C. Méndez-Ribas J. M., Midgley A. R. Jr. and Scaglia H. E.: Proc. VIII World Congr. Fertil. Steril. Buenos Aires, Argentina (1974) p. (Abstract).

12. Gual C.m Lichtenberg R., Schally A. V., Ortiz A., PérezPalacios G. and Midgley A. R. Ir.: In Hypothalamic Hypophysiotropic Hormones: Physiological and Clinical 
Studies (Edited by C. Gual and E. Rosemberg). Excerpta Medica Int. Congr. Series No. 263 (1972) p. 230, pp. 232-235.

13. Keye W. R. Jr. and Jaffe R. B.: J. clin. Endocr. Metab. 38 (1974) 805-815,

14. Yen S. S. C., Vandenberg G. and Siler T. M.: J. clin. Endocr. Metab. 39 (1974) 170-177.

15. Swerdloff R. S. and Odell W. D.: In Gonadotropins (Edited by E. Rosemberg). Geron-X, Inc., Los Altos, California (1968) p. 155, pp. 157-158.

16. Heller C. G., Morse H. C., Su M. and Rowley M. J.: In The Human Testis (Edited by E. Rosemberg and C. A. Paulsen). Plenum Press, New York, London, (1970) p. 249 , pp. $250-253$.

17. Peterson N. '1., Midgley A. R. Jr. and Jaffe R. B.: J. clin. Endocr. Metab. 28 (1968) 1473-1478.
18. Lee P. S., Jaffe R. B., Midgley A. R. Jr., Kohen F. and Niswender G. D.: J. clin. Endocr. Metáb. 35 (1972) 636-641.

19. Capell P. T. and Paulsen C. A.: Contraception 6 (1972) 135.

20. Smals A. G. H., Kloppenborg P. W. C. and Benraad Th. J.: Fourth International Congress on Hormonal Steroids, J. steroid Biochem. 5 (1974) 371.

21. Capell P. T., Paulsen C. A., Derleth D., Skoglund R. and Plymate S.: J. clin. Endocr. Metab. 37 (1973) 752 759.

22. Stewart-Bentley M., Odell W. and Horton R.: Proc. 53rd Meeting Endocr. Soc. San Francisco, Cal. (1971) p. A-80. (Abstract).

23. Scaglia H. E., Ramírez A. M., Gaitan R., Mendoza F. and Pérez-Palacios G.: (unpublished data). 